\title{
Lignocellulosic Materials as Dye Adsorbents: Adsorption of Methylene Blue and Congo Red on Brewers' Spent Grain
}

\author{
Antonija Kezerle, ${ }^{1}$ Natalija Velić, ${ }^{2, *}$ Damir Hasenay, ${ }^{3}$ Davor Kovačević ${ }^{4}$
}

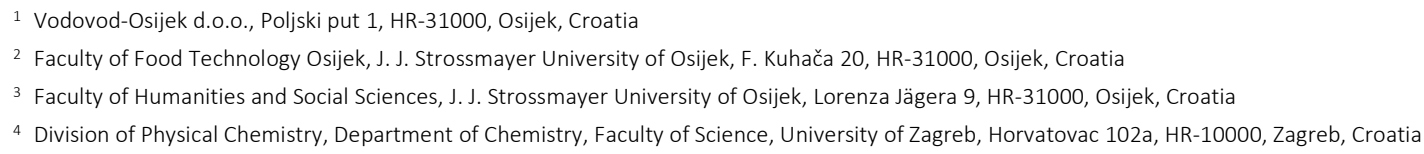

RECEIVED: January 20, 2018 * REVISED: March 12, 2018 * ACCEPTED: March 13, 2018

Abstract: Brewers' spent grain (BSG), a lignocellulosic waste material, was evaluated as a low-cost adsorbent for the removal of synthetic dyes methylene blue (MB) and Congo red (CR) from aqueous solutions in a batch process. Characterisation of the BSG was performed by chemical analysis, FTIR and SEM. The effects of contact time, initial dye concentration, adsorbent particle size, adsorbent concentration and pH on the adsorption process were investigated. High removal of both dyes ranging from 70 to over $90 \%$ was achieved. It was shown that in both cases ( $\mathrm{MB}$ and $\mathrm{CR}$ adsorption) the process could be interpreted in terms of Langmuir and Freundlich adsorption isotherms. The kinetics of the adsorption process was well described by the pseudo-second-order model. The results indicated the potential use of BSG as a low-cost adsorbent for $\mathrm{MB}$ and $\mathrm{CR}$ dye removal from aqueous solutions.

Keywords: adsorption, brewers' spent grain, Congo red, lignocellulose, methylene blue, synthetic dyes removal.

\section{INTRODUCTION}

D YES are natural or synthetic compounds, usually organic in nature, that provide bright and lasting colour to other substance. They are extensively used in many industries such as textile, leather, paper, pharmaceutical, cosmetic, food and much more. Most commonly used dyes are synthetic by origin and often have complex aromatic molecular structure. To date, there are over 100000 different synthetic dyes available commercially. ${ }^{[1]}$ Different industrial processes employing dyes are generators of a considerable amount of coloured wastewater. It has been reported that up to $1-10 \%$ of dyes used can be lost to industrial effluents during the production process. ${ }^{[2]}$ Apart from dyes, coloured wastewaters often contain other contaminants, e.g. textile wastewaters contain different salts that promote covalent bonding of dyes and fibres, as well as bases, acids and metals. ${ }^{[3]}$ Furthermore, it is often essential to maintain $\mathrm{pH}$ value of textile dye bath using buffer systems. ${ }^{[4]}$ Thus $\mathrm{pH}$ and ionic strength of coloured wastewaters are dependent on the production process. Synthetic dyes are distinguished by high stability to light, heat and oxidising agents; high solubility and recalcitrance towards biodegradation, which all leads to their prolonged persistence and bioaccumulation in the environment. ${ }^{[5,6]}$ When wastewaters that are treated inadequately are discharged to surface waters, they significantly reduce the oxygen concentration and light penetration of recipient, thus detrimentally affecting the aquatic ecosystems. ${ }^{[5]}$ Furthermore, many dyes pose toxicity (genotoxicity, mutagenicity and carcinogenicity) to aquatic organisms and can endanger human health via the food chain. ${ }^{[7,8,9]}$ Low biodegradability of dyes significantly impairs their removal efficiency by conventional biological wastewater treatment methods. ${ }^{[10]}$ The conventional methods employed for dye removal from wastewater are numerous. To name but few: adsorption, membrane separation, coagulation and flocculation, oxidation or ozonation. ${ }^{[11]}$ However, adsorption is by 
far the most often applied at industrial scale, due to its simplicity, versatility, efficiency and insensitivity to toxic pollutants. ${ }^{[12,13]}$ The main drawback is the relatively high cost of conventional adsorbents, such as the most widely used activated carbon. To address this problem, various low-cost adsorbents have been extensively investigated for dye removal from wastewaters. By definition, the low-cost adsorbent is abundant in nature or is an industrial byproduct or waste material that requires no or little processing. ${ }^{[12]}$ Lignocellulosic waste materials arising from food and wood industry or agriculture represent a potential alternative to conventional adsorbents. Different adsorbents derived from industrial or agricultural wastes have been successfully used for dye removal from an aqueous solution such as apple pomace, ${ }^{[14,15]}$ peanut hull,, ${ }^{[1]}$ sugar bagasse, ${ }^{[16,17]}$ sugar beet waste, ${ }^{[15]}$ barley husk, ${ }^{[18]}$ brewers' spent grain, ${ }^{19,20]}$ wood sawdust, ${ }^{[15,21]}$ fruit and vegetable peels, ${ }^{[22,11]}$ etc. The main components of lignocellulosic materials responsible for adsorption are polymers: cellulose, hemicellulose and lignin, i.e. the adsorption is achieved through the interaction of dyes and functional groups of these polymers (e.g. $-\mathrm{OH}$ and $-\mathrm{COOH}$ ). When used as biosorbents, lignocellulosic materials often undergo different modifications in order to improve their adsorption characteristics. Modifications include physical modifications (size reduction, heat treatment), chemical modifications (using acids, bases or organic solvents) and pyrolysis. ${ }^{[23]}$ Brewers' spent grain (BSG) is brewery lignocellulosic waste material that accounts for $85 \%$ of the total waste production in the brewery ${ }^{[24]}$ and thus is widely available throughout the year. So far BSG was mostly used as feed or has been landfilled, and its exploitation as a valuable renewable resource has been neglected. ${ }^{[25]}$ However, different investigations were conducted in order to evaluate BSG as an adsorbent for the removal of synthetic dyes, namely acid dyes - green, yellow, blue and orange 7,,[20,26,27] Basic Blue 41, Reactive Black 5, and Acid Black 1, ${ }^{[28]}$ malachite green, ${ }^{[15]}$ methylene blue, ${ }^{[19]}$ and Congo red. ${ }^{[29]}$ Methylene blue (MB) is a cationic (basic) dye most commonly used for cotton, silk and leather dyeing. ${ }^{[30]}$ The chemical structure of $M B$ is given in Figure 1a. Apart from being used as a dye, MB also has many uses in medicine such as the use in diagnostic microbiology as a stain, treatment of hypotension, hypoxia, preoperative use in cardiac surgery, treatment of severe vasoplegia, use as antimalarial and more. It is considered a safe drug when used in therapeutic doses of less than $2 \mathrm{mg}$ $\mathrm{kg}^{-1}{ }^{[31]}$ Even though it is not strongly hazardous, it can cause various harmful effects in humans and animals, such as skin irritations, permanent eyes injuries, irritation of gastrointestinal tract - nausea, vomiting and diarrhoea, cyanosis, dyspnoea, convulsions and tachycardia. ${ }^{[30,31,32]}$ Congo red (CR) is an anionic dye that belongs to azo class of dyes (Figure 1b), the most widely used class of dyes. It has been<smiles></smiles>

(a)<smiles>Nc1c(N=Nc2ccc(-c3ccc(N=Nc4cc(S(=O)(=O)O[Na])c5ccccc5c4N)cc3)cc2)ccc2c(S(=O)(=O)O)cccc12</smiles>

(b)

Figure 1. Chemical structures of MB (a) and CR (b).

extensively used in textile, paper, plastic and rubber industries. Furthermore, it has been used in microbiology for staining and for diagnostic purposes for staining amyloid in tissues of patients. CR proved to be toxic to many organisms and is suspected to be carcinogenic and mutagenic. Furthermore, it is hard to biodegrade due to its complex chemical structure. ${ }^{[33]}$

The aim of this study was to evaluate the potential of BSG as a low-cost adsorbent for the removal of synthetic dyes from buffered aqueous solutions. Widely used cationic dye MB and anionic azo dye CR were used as model dyes. Different factors influencing the adsorptive dye removal were investigated in order to find the optimum conditions for the efficient adsorption of dyes onto BSG: initial dye concentration, contact time, adsorbent size, adsorbent concentration and solution $\mathrm{pH}$. This study provides the insight into potential application of widely available waste material BSG for adsorptive dye removal from aqueous solutions.

\section{EXPERIMENTAL}

\section{Adsorbent}

BSG was kindly donated by brewery "Osječka pivovara d.d.", Osijek, Croatia. Within few hours of collection from the mash tun BSG was spread on trays and oven dried at $60{ }^{\circ} \mathrm{C}$ for $48 \mathrm{~h}$, to prevent microbial spoilage. Dried BSG (8\% moisture) was ground using standard laboratory knife mill with $1 \mathrm{~mm}$ screen (MF10 basic, IKA Labortechnik, Germany) and passed through the set of sieves mesh sizes 500, 400, $300,200,100$ and $53 \mu \mathrm{m}$ using a vibratory sieve shaker (AS 200 Digit, Retsch GmbH, Germany). The mass of BSG retained on each sieve was measured and the percentage of the total mass of the BSG sample was calculated. No other chemical or physical treatments were applied prior to adsorption experiments.

\section{Adsorbent Characterisation}

The moisture content of dried BSG was determined 
thermogravimetrically using moisture analyser (HR73 Moisture Analyser, Mettler Toledo, Switzerland). The determination of ash content and extractives was described elsewhere. ${ }^{[34]}$ Protein content was determined using the Kjeldahl method. Lignin and cellulose contents were determined according to the procedures described elsewhere. ${ }^{[35,36]}$ The surface functional groups of BSG affecting the adsorption were detected by Fourier transforms infrared (FTIR) spectrometer (Cary 630, Agilent Technologies). The spectra were recorded from 4000 to $400 \mathrm{~cm}^{-1}$. BSG morphology and surface characteristics were studied using field emission scanning electron microscope (FE SEM, JOEL, JSM-7000F).

\section{Adsorbates}

$\mathrm{MB}$ and $\mathrm{CR}$ used in this study were purchased from Merck and Fischer Scientific, respectively. Dried BSG added to MB and $\mathrm{CR}$ aqueous dye solutions yielded $\mathrm{pH}$ lower than 5 . Thus it was decided to dissolve the dyes in buffer $\mathrm{pH}=7$, obtaining the solutions that partially simulate coloured industrial effluents. A stock solution of $500 \mathrm{mg} \mathrm{dm}^{-3}$ of individual dyes was prepared by dissolving the exact quantity of dye in previously prepared $\mathrm{pH}=7$ buffer solution $(0.025$ $\mathrm{mol} \mathrm{dm}{ }^{-3} \mathrm{Na}_{2} \mathrm{HPO}_{4} / 0.025 \mathrm{~mol} \mathrm{dm}{ }^{-3} \mathrm{KH}_{2} \mathrm{PO}_{4}$ ). The experimental solutions were obtained by diluting the stock solution with buffer to the desired dye concentration.

\section{Batch Adsorption Studies}

$A$ batch technique was used for the investigation of $M B$ and CR adsorption on BSG. A fixed amount of BSG (1 g) was added to a series of $250 \mathrm{~cm}^{3}$ conical flasks containing 100 $\mathrm{cm}^{3}$ of dye solutions of different initial concentrations (15$150 \mathrm{mg} \mathrm{dm}^{-3}$ ) at constant $\mathrm{pH}$. The flasks were placed in the incubator shaker (INNOVA 4340, New Brunswick Scientific, New Jersey, USA) at $298.15 \mathrm{~K}$ and $150 \mathrm{rpm}$ for $240 \mathrm{~min}$, to ensure equilibrium was reached. Flasks were collected from the incubator at predetermined time intervals for spectrophotometric determination of colour removal. The samples were filtered through Whatman filter paper No. 42 and then centrifuged at $10000 \mathrm{rpm}$ for $5 \mathrm{~min}$ (Tehtnica Centric 322A, Domel d.o.o., Slovenia). The dye concentrations in clarified supernatants were determined immediately using spectrophotometer (Lambda 25, Perkin Elmer, USA) at appropriate wavelengths (MB $664 \mathrm{~nm}$ and CR 498 $\mathrm{nm}$ ). The percent of dye removal was calculated by the following equation:

$$
\% \text { dye removal }=\frac{\gamma_{0}-\gamma}{\gamma_{0}} \cdot 100
$$

where $\gamma_{0}$ and $\gamma$ (in $\mathrm{mg} \mathrm{dm}^{-3}$ ) are the initial dye concentration and dye concentration after predetermined contact time, respectively.
The amount of dye adsorbed at equilibrium onto BSG, $q_{\mathrm{e}}$ (in $\mathrm{mg} \mathrm{g}^{-1}$ ), was calculated as follows:

$$
q_{\mathrm{e}}=\frac{\left(\gamma_{0}-\gamma_{\mathrm{e}}\right) \cdot V}{m}
$$

where $\gamma_{\mathrm{e}}$ is the dye concentration at equilibrium (in $\mathrm{mg} \mathrm{dm}^{-3}$ ), $V$ is the dye solution volume (in $\mathrm{dm}^{3}$ ) and $m$ is the mass of adsorbent used (in g).

To study the effect of BSG particle size on the amount of dye adsorption, three particle size ranges (53$100 \mu \mathrm{m}, 100-400 \mu \mathrm{m}$ and $400-500 \mu \mathrm{m}$ ) were used while keeping all the other parameters constant $\left(\gamma_{\text {dye }}=30 \mathrm{mg}\right.$ $\mathrm{dm}^{-3}, m_{\text {adsorbent }}=1 \mathrm{~g}, V_{\text {dye solution }}=100 \mathrm{~cm}^{3}, \mathrm{pH}=6.8, t=240$ $\min , T=298.15 \mathrm{~K}, 150 \mathrm{rpm})$. The effect of BSG concentration on the amount of dye adsorbed was studied by adding different amounts of BSG $(0.5,1.0$ and $1.5 \mathrm{~g})$ to a definite volume of dye solution $\left(V=100 \mathrm{~cm}^{3}\right)$ and keeping all other parameters constant $\left(\gamma_{\text {dye }}=30 \mathrm{mg} \mathrm{dm}^{-3}, \mathrm{pH}=6.8, t=240\right.$ $\min , T=298.15 \mathrm{~K}, 150 \mathrm{rpm}$ ).

To study the effect of solution $\mathrm{pH}$ on dye adsorption on BSG, $30 \mathrm{mg} \mathrm{dm}^{-3}$ dye solution was prepared in a series of different buffers as follows: $\mathrm{pH}=4\left(0.05 \mathrm{~mol} \mathrm{dm}^{-3}\right.$ potassium hydrogen phthalate, $\left.\mathrm{C}_{8} \mathrm{H}_{5} \mathrm{KO}_{4}\right), \mathrm{pH}=6\left(0.1 \mathrm{~mol} \mathrm{dm}^{-3}\right.$ $\left.\mathrm{C}_{8} \mathrm{H}_{5} \mathrm{KO}_{4} / 0.1 \mathrm{~mol} \mathrm{dm}^{-3} \mathrm{NaOH}\right), \mathrm{pH}=8\left(0.2 \mathrm{~mol} \mathrm{dm}^{-3} \mathrm{H}_{3} \mathrm{BO}_{3} /\right.$ $\left.1 \mathrm{~mol} \mathrm{dm}^{-3} \mathrm{NaOH} / 0.1 \mathrm{~mol} \mathrm{dm} \mathrm{m}^{-3} \mathrm{HCl}\right), \mathrm{pH}=9\left(0.2 \mathrm{~mol} \mathrm{dm}^{-3}\right.$ $\mathrm{H}_{3} \mathrm{BO}_{3} / 1 \mathrm{~mol} \mathrm{dm}^{-3} \mathrm{NaOH} / 0.1 \mathrm{~mol} \mathrm{dm}^{-3} \mathrm{HCl}$ ), and $\mathrm{pH}=10$ ( $0.025 \mathrm{~mol} \mathrm{dm}^{-3} \mathrm{Na}_{2} \mathrm{CO}_{3} / 0.025 \mathrm{~mol} \mathrm{dm}^{-3} \mathrm{NaHCO}_{3}$ ).

The linear forms of Langmuir and Freundlich adsorption models were employed in describing the adsorption process. The kinetics of $\mathrm{MB}$ and $\mathrm{CR}$ adsorption were analysed by fitting the data to pseudo-first-order, pseudosecond-order and intraparticle diffusion models.

All the above-described experiments were performed in duplicate and were found reproducible.

\section{RESULTS AND DISCUSSION}

\section{Adsorbent Characterization}

To assess the chemical composition of BSG, a series of analysis was performed and the results are given in Table 1. As can be seen from the table, the lignocellulosic polymers lignin and cellulose comprise over $45 \%$ of BSG's dry weight, while proteins account for another $21 \%$. The obtained results are consistent with the results of other studies reviewed by Mussato et al. ${ }^{[24]}$ However, it is important to note that BSG's chemical composition can considerably vary between different breweries, due to variation in technology or differences in malt used during brewing. ${ }^{[37]}$

To investigate the qualitative adsorption characteristics of BSG's surface functional groups, FTIR spectra were recorded and the results are presented in Figure 2. The spectra revealed a number of adsorption peaks, indicating 
Table 1. Chemical composition of BSG

\begin{tabular}{lc}
\hline Compound & \% dry weight \\
\hline Ash & 3.5 \\
Extractives $^{(a)}$ & 10.2 \\
Total lignin & 23.6 \\
$\quad$ Klason lignin & 14.5 \\
Acid soluble lignin & 9.1 \\
Cellulose & 22.0 \\
Proteins & 21.0 \\
Undetermined & 19.7 \\
\hline (a) ethanol/benzene (1:1)
\end{tabular}

the complex nature of the BSG. FTIR spectrum of BSG is dominated by the broad bands at $3280 \mathrm{~cm}^{-1}$ representing hydroxyl groups $(-\mathrm{OH})$. The bands are attributed to $\mathrm{O}-\mathrm{H}$ stretching vibrations due to inter and intramolecular hydrogen bonding of polymeric compounds, such as cellulose and lignin, indicating the presence of free hydroxyl groups at the adsorbent surface. The bands with two maxima at 2922 and $2855 \mathrm{~cm}^{-1}$ could be ascribed to aliphatic $(-\mathrm{CH})$ groups stretching. In the $2000-400 \mathrm{~cm}^{-1}$ region, the spectrum is dominated by the intense band at $1036 \mathrm{~cm}^{-1}$ probably arising from the polysaccharides, i.e. it could be assigned to $\mathrm{C}-\mathrm{O}, \mathrm{C}=\mathrm{C}$ and $\mathrm{C}-\mathrm{C}-\mathrm{O}$ stretching in cellulose, hemicellulose and lignin. Furthermore, the band observed at $1625 \mathrm{~cm}^{-1}$ could be assigned to a carbonyl group $(\mathrm{C}=\mathrm{O})$ of unionised carboxylate stretching of carboxylic acid, while the peak at
$1535 \mathrm{~cm}^{-1}$ could be assigned to aromatic ring vibration from lignin. The band at $521 \mathrm{~cm}^{-1}$ could be ascribed to ester vibrations and monosubstituted aromatic rings of the lignin fraction. The shifting of peak positions, i.e. the change in the frequency of peaks and intensity of peaks of dye-loaded BSG samples compared to that of BSG that can be observed from the spectra, indicate the adsorption of dyes at the surface of BSG.

In order to study the surface morphology of BSG, the most commonly used characterization technique, i.e. scanning electronic microscopy (SEM), was employed. The surface morphology of BSG at 1000, 2000, 5000 and 10000 magnifications is shown in Figure 3. The figures revealed the irregular shape of BSG particles, as well as a rough surface containing micropores, that may provide substantial adsorption surface for dyes.

\section{Batch Adsorption Studies}

\section{Effect of Initial Dye Concentration and Contact Time on Dye Adsorption}

The contact time between the adsorbent and the dye has a strong effect on the adsorption process. Figure 4 shows the effect of the initial dye concentration and contact time on $\mathrm{MB}$ and $\mathrm{CR}$ adsorption to BSG. The adsorption increased with the increase of contact time and the increase of initial dye concentration. The amount of MB removed at equilibrium increased from 1.35 to $12.8 \mathrm{mg} \mathrm{g}^{-1}$, while the amount of removed CR increased from 1.41 to $13.21 \mathrm{mg} \mathrm{g}^{-1}$ when the initial dye concentration increased from 15 to $150 \mathrm{mg}$

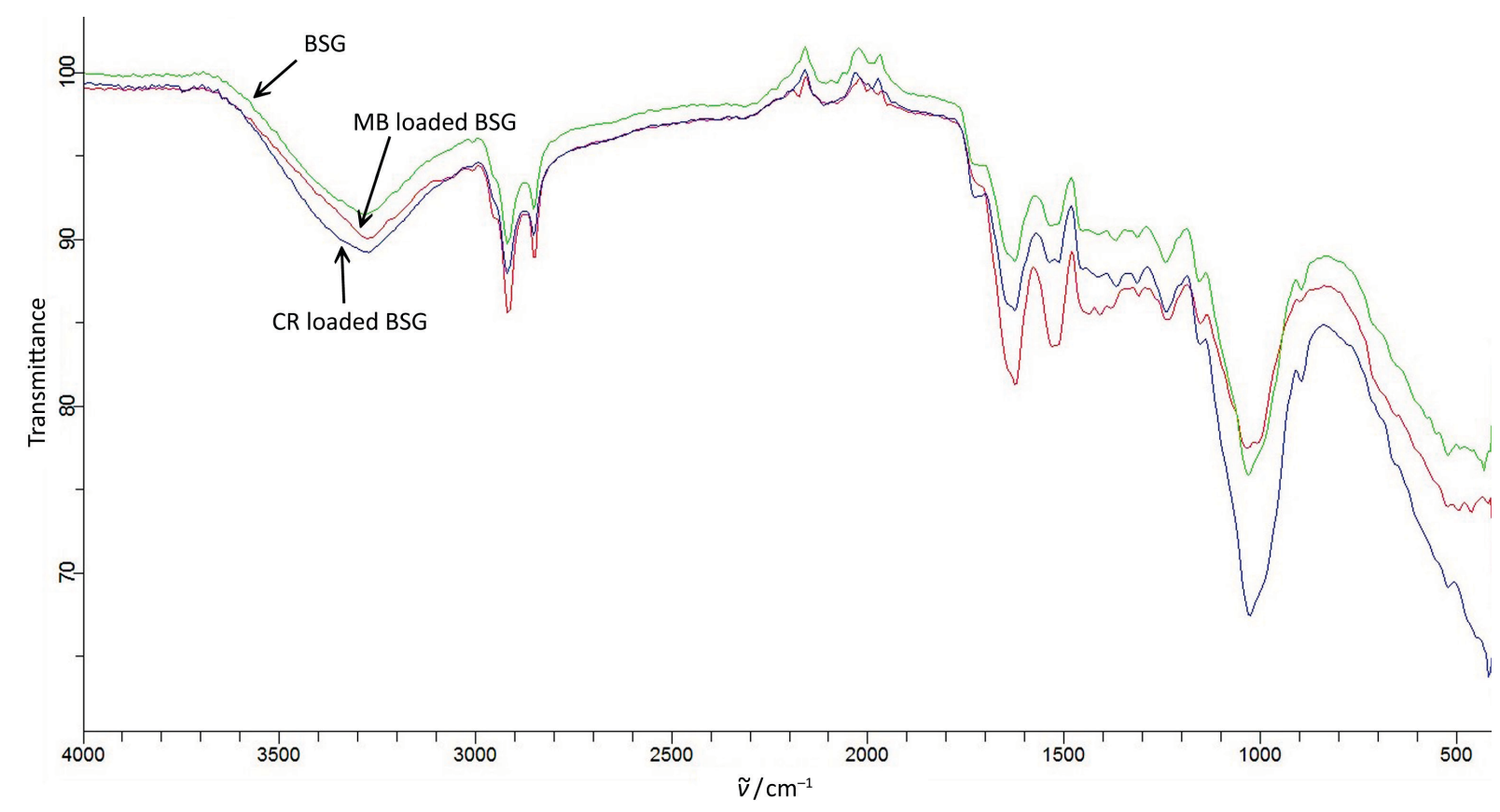

Figure 2. The FTIR spectral characteristics of BSG before and after MB and CR adsorption. 

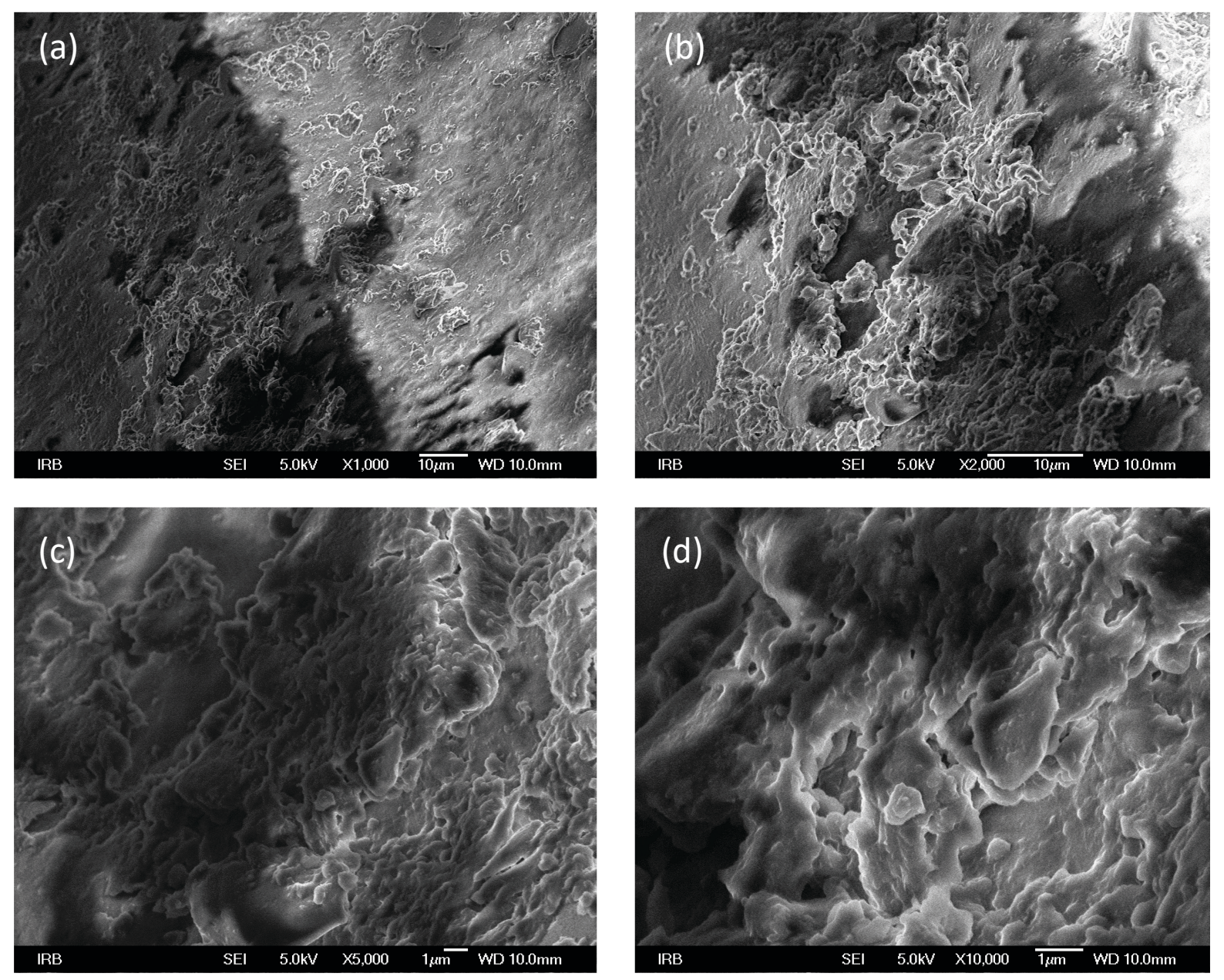

Figure 3. SEM micrograph of BSG at different magnifications: 1000 (a), 2000 (b), 5000 (c), 10000 (d).

$\mathrm{dm}^{-3}$. These results indicated that the $\mathrm{MB}$ and $\mathrm{CR}$ adsorptive removal using BSG is dependent on the concentration of dye and are consistent with those of other studies using different biosorbents for $\mathrm{MB}$ and $\mathrm{CR}$ removal, such as garlic peel, [11] jackfruit peel, ${ }^{[38]}$ neem sawdust, ${ }^{[39]}$ roots of Eichhornia crassipes, ${ }^{[40]}$ and waste banana pith. ${ }^{[41]}$ Higher initial concentration results in a higher concentration gradient, thus providing the higher driving force to overcome the resistance to the dye mass transfer between the two phases - the aqueous and solid. Consequently, the amount of dye adsorbed at equilibrium increased. ${ }^{[42]}$ Table 2 gives a shortened overview of the effect of contact time and initial dye concentration on the percentage of dye removal. Removal of both dyes is characterised by rapid removal during the first 20 min of the experiment. After the initial rapid dye removal, at later stages, the removal becomes slower until equilibrium is achieved. The higher removal rate at the initial stages of the adsorption process can be attributed to the larger unoccupied surface area available for dye adsorption, while at later stages there are fewer remaining unoccupied surface sites and the removal rate becomes slower. ${ }^{[40]}$ The adsorption removal of both dyes was characterised by a high percentage of dye removal (85-96\%) independent of the applied dye concentration.

\section{Effect of Adsorbent Particle Size and Concentration on Dye Adsorption}

The effect of particle size on the adsorption of $M B$ and $C R$ onto BSG is shown in Figure 5. Three particle size ranges were selected based on the results of the milled BSG particle size determination by sieve analysis (data not shown), namely 53-100 $\mu \mathrm{m}, 100-400 \mu \mathrm{m}$ and $400-500 \mu \mathrm{m}$. $97 \%$ of all BSG particles were distributed among the ranges mentioned above. The sieve analysis results revealed that the highest percentage of the total mass of the BSG sample used for the analysis (68\%) were particles ranging from 100 to $400 \mu \mathrm{m}$. In respect to the possible application of BSG for dye removal at industrial scale, it is important to choose the particle size range that will ensure the least possible amount of discarded adsorbent material, while keeping the 

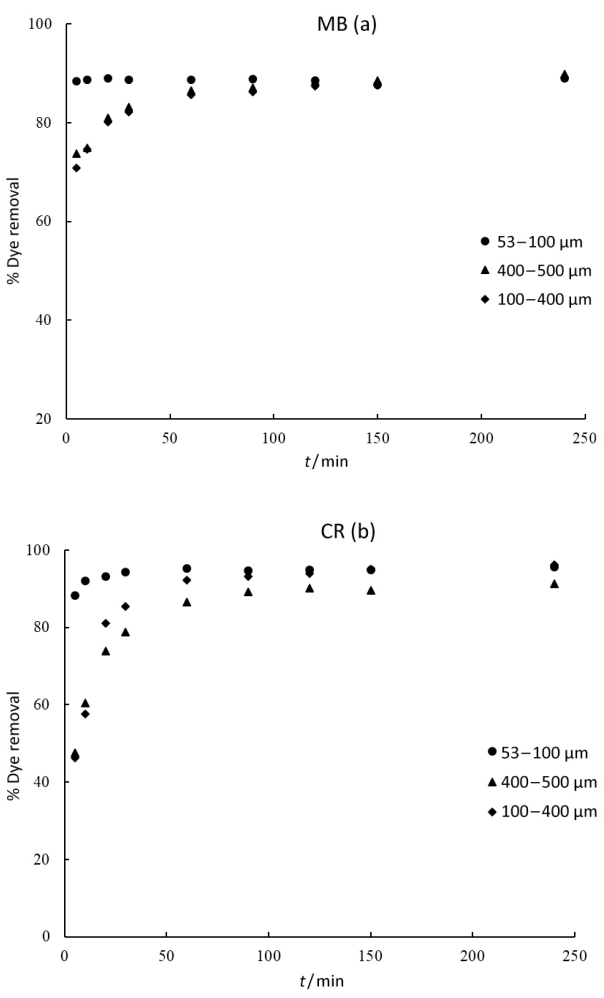

Figure 5. The effect of particle size on the adsorption of $\mathrm{MB}(\mathrm{a})$, and $\mathrm{CR}$ (b) onto BSG. $\gamma_{\text {dye }}=30 \mathrm{mg} \mathrm{dm}^{-3}, t=240 \mathrm{~min}$, $T=298.15 \mathrm{~K}, m_{\text {adsorbent }}=1 \mathrm{~g}, V_{\text {dye solution }}=100 \mathrm{~cm}^{3}, \mathrm{pH}=6.8$.

high removal percentage. As can be seen from the Figure 5 the effect of particle size is evident during the first $50 \mathrm{~min}$ of the experiment, i.e. the amount of dye adsorbed increased as the particle size of the adsorbent decreased. This can probably be attributed to the fact that smaller particles provide a larger external surface area per unit mass, thus removing more dye at the initial stages of the experiment. ${ }^{[39]}$ At later stages of the experiment, the effect of particle size on dye adsorption was not prominent. The adsorption is usually strongly affected by the adsorbent concentration, because of the surface area available for adsorption. The effect of adsorbent concentration on the
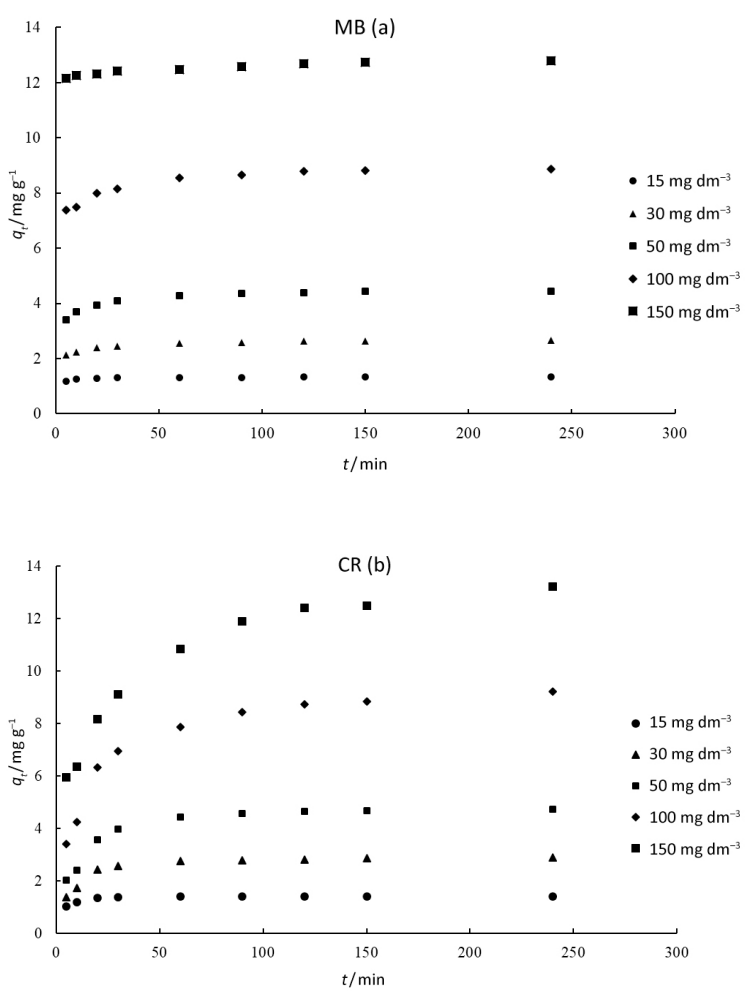

Figure 4. The effect of the initial dye concentration and contact time on $\mathrm{MB}$ adsorption (a), and $\mathrm{CR}$ adsorption (b). $T=298.15 \mathrm{~K}, m_{\text {adsorbent }}=1 \mathrm{~g}, V_{\text {dye solution }}=100 \mathrm{~cm}^{3}, \mathrm{pH}=6.8$.

percentage removal of $M B$ and $C R$ is presented in Figure 6 . Both $\mathrm{MB}$ and $\mathrm{CR}$ percentage removal increased with the increase of adsorbent concentration, which was explicitly evident during the initial stages of the adsorption process. This is in agreement with the report of the MB adsorption on Oleander plant tissues, ${ }^{[43]}$ as well as the adsorption of $\mathrm{CR}$ onto E. crassipes roots. ${ }^{[40]}$

\section{Effect of Solution pH on Dye Adsorption}

Generally, $\mathrm{pH}$ is an important factor affecting the adsorptive removal of different contaminants from wastewater. ${ }^{[42]}$ The effect of solution $\mathrm{pH}$ on the amount of dye

Table 2. The effect of contact time and initial dye concentration on MB and CR removal by BSG. $T=298.15 \mathrm{~K}, m_{\text {adsorbent }}=1 \mathrm{~g}$, $V_{\text {dye solution }}=100 \mathrm{~cm}^{3}, \mathrm{pH}=6.8$

\begin{tabular}{ccccccc}
\hline & & \multicolumn{5}{c}{ Initial dye concentration $/ \mathrm{mg} \mathrm{dm}^{-3}$} \\
\cline { 3 - 7 } Dye & $t / \min$ & 15 & 30 & 50 & 100 & 150 \\
\cline { 3 - 7 } & & & \multicolumn{5}{c}{ Dye removal / \% } \\
\hline \multirow{2}{*}{ MB } & 20 & 85.73 & 80.10 & 78.82 & 79.91 & 82.13 \\
& 240 & 89.87 & 89.10 & 88.89 & 88.57 & 85.33 \\
\hline \multirow{2}{*}{ CR } & 20 & 89.00 & 81.04 & 71.33 & 69.47 & 60.73 \\
& 240 & 93.43 & 96.19 & 94.72 & 92.15 & 88.04 \\
\hline
\end{tabular}



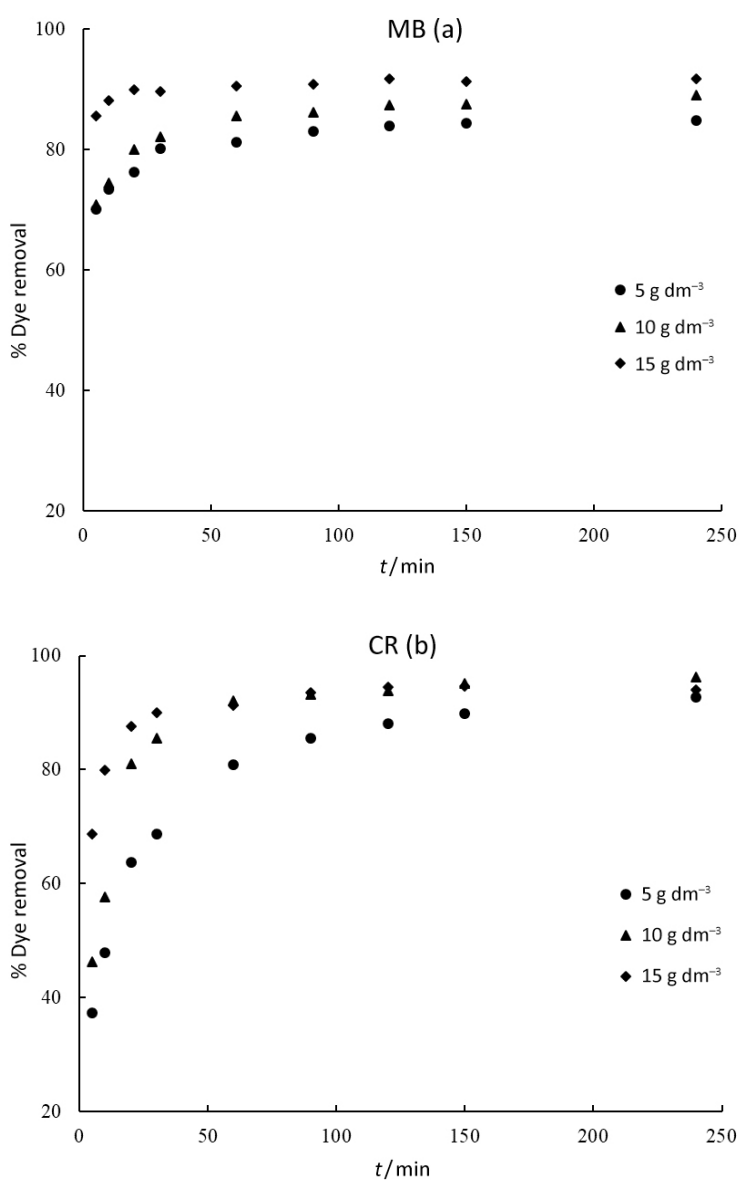

Figure 6. The effect of adsorbent concentration on the adsorption of $\mathrm{MB}(\mathrm{a})$, and $\mathrm{CR}(\mathrm{b})$ onto BSG. $\gamma_{\text {dye }}=30 \mathrm{mg} \mathrm{dm}^{-3}$, $t=240 \mathrm{~min}, T=298.15 \mathrm{~K}, \mathrm{pH}=6.8$.

adsorbed on BSG at equilibrium was investigated for $\mathrm{MB}$ and $\mathrm{CR}$ dissolved in a series of different buffers over the $\mathrm{pH}$ range of 4-10. The results are presented in Figure 7 show that the amount of $\mathrm{MB}$ adsorbed was minimal at $\mathrm{pH}=4$, increased with $\mathrm{pH}$ up to $\mathrm{pH}=8$ and then remained constant over the $\mathrm{pH}$ range $8-10$. This is in agreement with the study of adsorptive $\mathrm{MB}$ removal using garlic peel[11] that also reported constant dye adsorption over the $\mathrm{pH}$ range 6-12 and lower adsorption at acidic $\mathrm{pH}$. The unfavourable effect of low $\mathrm{pH}$ on MB removal was also reported by other studies using different adsorbents, such as cedar sawdust, ${ }^{[44]}$ spent mushroom substrate, ${ }^{[45]}$ jackfruit peel, ${ }^{[38]}$ cellolignin - a wood industry by-product, ${ }^{[46]}$ etc. Less efficient MB removal at low $\mathrm{pH}$ can probably be attributed to the presence of positively charged $\mathrm{H}^{+}$ions that compete with $\mathrm{MB}$ cations for adsorption sites. The amount of $\mathrm{CR}$ adsorbed was minimal at $\mathrm{pH}=4$, increased up to $\mathrm{pH}=7$ and then decreased over the $\mathrm{pH}$ range $8-10$. These results differ from the published study that reported the maximum $C R$ adsorption at $\mathrm{pH}=5$ and constant percentage of removal

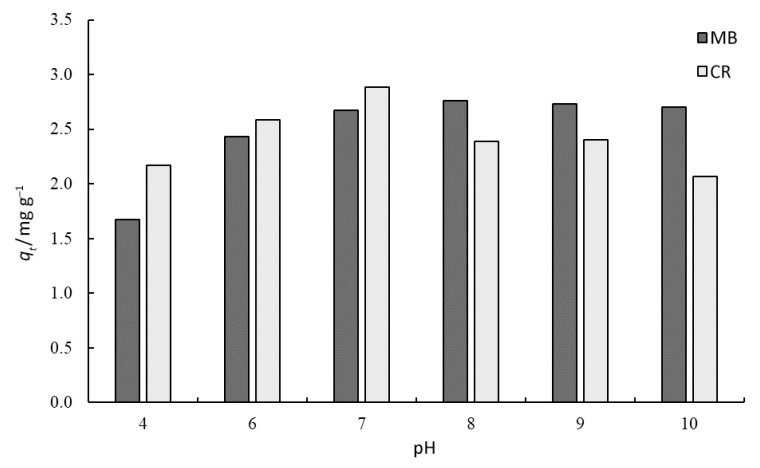

Figure 7. The effect of $\mathrm{pH}$ on the adsorption of $\mathrm{MB}$ and $\mathrm{CR}$ onto BSG. $\gamma_{\text {dye }}=30 \mathrm{mg} \mathrm{dm}^{-3}, t=240 \mathrm{~min}, T=298.15 \mathrm{~K}$, $m_{\text {adsorbent }}=1 \mathrm{~g}, V_{\text {dye solution }}=100 \mathrm{~cm}^{3}, \mathrm{pH}=6.8$.

over $\mathrm{pH}$ range of 5.5-10.0 when cattail root was used as an adsorbent. ${ }^{[4]}$ Furthermore, the study that used waste banana pith as adsorbent reported $92 \%$ CR removal in the $\mathrm{pH}$ range $2-11,{ }^{[41]}$ while the study that used cassava residue also reported that $\mathrm{pH}$ did not markedly affect the adsorptive capacity. ${ }^{[48]}$ The discrepancy in the results between our study and the studies mentioned above may be attributed to the fact that buffered aqueous CR solution was used in our study. Even though buffers could interfere with the dye adsorption to some extent, ${ }^{[4]}$ the removal efficiencies of both $\mathrm{MB}$ and $\mathrm{CR}$ in this study were in the range of $70-90 \%$ over the entire $\mathrm{pH}$ range from 4 to 10 , regardless the used buffer.

\section{Adsorption Equilibrium}

The adsorption isotherm describes how the adsorbate molecules distribute between the liquid and solid phase at the adsorption equilibrium, and offers some insight of the adsorption capacity of the adsorbent. ${ }^{[11]}$ The adsorption data were fitted to the Langmuir and Freundlich equations.

\section{Langmuir Isotherm}

Langmuir isotherm model presumes the occurrence of adsorption at specific adsorbent homogenous sites as a monolayer. Furthermore, the model assumes the availability of a fixed number of adsorption sites and the reversible nature of adsorption. ${ }^{[49]}$ The linear form of Langmuir isotherm ${ }^{[50]}$ equation used is represented by the following equation:

$$
\frac{\gamma_{\mathrm{e}}}{q_{\mathrm{e}}}=\frac{1}{q_{\mathrm{m}}} \cdot \gamma_{\mathrm{e}}+\frac{1}{K_{L} \cdot q_{\mathrm{m}}}
$$

where $\gamma_{\mathrm{e}}$ (in $\mathrm{mg} \mathrm{dm}^{-3}$ ) is the equilibrium concentration, $q_{\mathrm{e}}$ $\left(\mathrm{mg} \mathrm{g}^{-1}\right.$ ) is the amount of dye adsorbed per unit mass of adsorbate, $q_{\mathrm{m}}$ (in $\mathrm{mg} \mathrm{g}^{-1}$ ) is the maximum amount of dye adsorbed (monolayer adsorption capacity) and $K_{\mathrm{L}}\left(\mathrm{dm}^{3} \mathrm{mg}^{-1}\right)$ is the Langmuir constant related to the free energy of adsorption. Both $q_{\mathrm{m}}$ and $K_{\mathrm{L}}$ can be predicted from the plot 


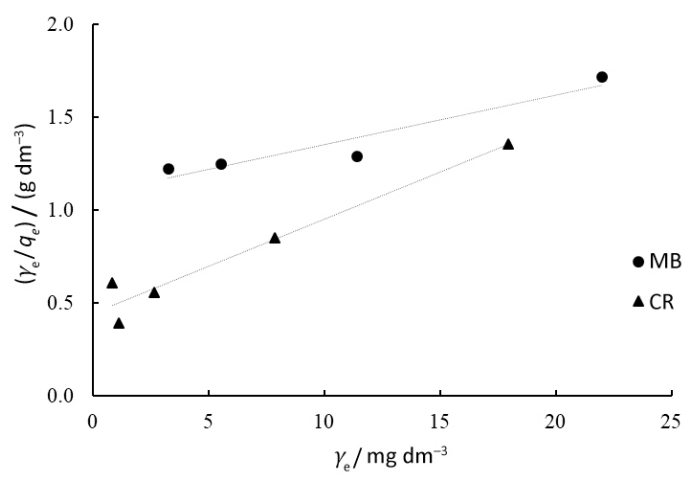

Figure 8. Langmuir isotherm of $M B$ and $C R$ adsorption on BSG at $298.15 \mathrm{~K}$.

of $\gamma_{\mathrm{e}} / q_{\mathrm{e}}$ against $\gamma_{\mathrm{e}}$ (Figure 8). The Langmuir isotherm parameters obtained in this study are given in Table 3 . The dimensionless constant called equilibrium parameter $R_{\mathrm{L}}$ represents the essential characteristics of the Langmuir isotherm and can be calculated by the following equation:

$$
R_{L}=\frac{1}{1+K_{L} \cdot \gamma_{0}}
$$

Where $\gamma_{\mathrm{o}}$ (in $\mathrm{mg} \mathrm{dm}^{-3}$ ) is the highest initial dye concentration. The $R_{\mathrm{L}}$ values indicate the type of isotherm to be unfavourable $\left(R_{\mathrm{L}}>1\right)$, favourable $\left(0<R_{\mathrm{L}}<1\right)$, linear $\left(R_{\mathrm{L}}=1\right)$ or irreversible $\left(R_{\mathrm{L}}=0\right) .{ }^{[16]}$ The $R_{\mathrm{L}}$ values in this study were 0.214 and 0.055 for $M B$ and $C R$, respectively, confirming that $\mathrm{MB}$ and $\mathrm{CR}$ adsorption onto BSG under studied conditions was a favourable process. However, when experimentally obtained $q_{\mathrm{m} \text { exp }}$ values were compared to the $q_{\mathrm{m} \text { cal }}$ values calculated on the basis of Eq. 3, the comparison revealed that $C R$ equilibrium data were in better accordance with Langmuir isotherm equation than $\mathrm{MB}$ data.

However, it should be taken into account that the basic assumptions of classical Langmuir equation are not easily met under real experimental conditions since the deviation of a real adsorption system from the ideal one was not accounted in the derivation process of the classical Langmuir equation.

\section{Freundlich Isotherm}

The Freundlich isotherm model describes the non-ideal adsorption on heterogeneous surfaces and multilayer adsorption, with no uniform distribution of adsorption heat. The linear form of the Freundlich equation ${ }^{[51]}$ can be expressed as:

$$
\ln q_{\mathrm{e}}=\ln K_{\mathrm{F}}+\frac{1}{n} \cdot \ln \gamma_{\mathrm{e}}
$$

where $q_{\mathrm{e}}$ (in $\mathrm{mg} \mathrm{g}^{-1}$ ) is the amount of dye adsorbed at equilibrium and $\gamma_{\mathrm{e}}\left(\mathrm{in} \mathrm{m} \mathrm{dm}^{-3}\right)$ is the equilibrium concentration of dye in solution. $K_{\mathrm{F}}$ and $n$ are Freundlich isotherm constants indicating the adsorbent adsorption capacity $\left(K_{\mathrm{F}}\right)$ and the favourability of the adsorption process $(n)$. The

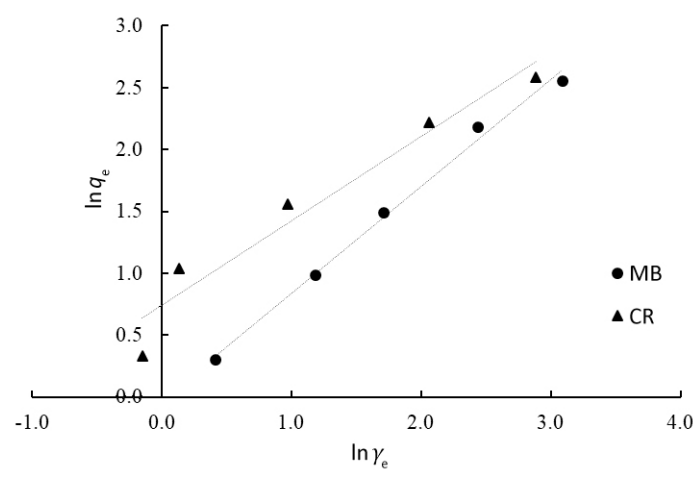

Figure 9. Freundlich isotherm of $M B$ and $C R$ adsorption on BSG at $298.15 \mathrm{~K}$.

calculated Freundlich constants are also given in Table 3 . The values of $n$ give the measure of deviation from linearity of the adsorption, and it has been proposed that $n=1$ means that adsorption is linear, $n<1$ indicates that adsorption is a chemical process, while $n>1$ indicates favourable adsorption achieved by the physical process. ${ }^{[16]}$ The results presented in Figure 9 and Table 3 (Freundlich isotherm parameters) indicate that the adsorption of $\mathrm{MB}$ and CR onto BSG is favourable and experimental data can be described by the Freundlich model.

\section{Adsorption Kinetics}

Generally, adsorption kinetics could be analysed by means of various linear ${ }^{[52,53]}$ and non-linear ${ }^{[54]}$ forms of models. Here, the experimental kinetics data of $\mathrm{MB}$ and $\mathrm{CR}$ adsorption onto BSG were fitted using three selected models: linear pseudo-first-order and pseudo-second-order models and intraparticle diffusion kinetic model. The summarised kinetic parameters of the pseudo-first-order and pseudosecond-order models and linear plots of intraparticle diffusion kinetic model are shown in Tables 4 and 5 and Figure 10 , respectively.

\section{Pseudo-first-order and Pseudo-second-order Models} One of the most widely used adsorption rate equations applicable for the liquid/solid system adsorption based on the adsorbent (solid) capacity is the Lagergren ${ }^{[52]}$ equation represented as follows:

$$
\ln \left(q_{\mathrm{e}}-q_{\mathrm{t}}\right)=\ln q_{\mathrm{e}}-k_{1} t
$$

where $q_{\mathrm{e}}$ and $q_{t}$ (in $\mathrm{mg} \mathrm{g}^{-1}$ ) are the amounts of dye adsorbed at equilibrium and at time $t$ (in $\mathrm{min}$ ), respectively. $k_{1}$ (in $\mathrm{min}^{-1}$ ) is the pseudo-first-order adsorption rate constant. The adsorption rate constant $k_{1}$ and $q_{\mathrm{e}}$ were calculated from the plots of $\ln \left(q_{\mathrm{e}}-q_{t}\right)$ vs. $t$ for different initial concentrations of $\mathrm{MB}$ and $\mathrm{CR}$. This model assumes that the rate of adsorption is proportional to the number of the sites unoccupied by the solutes. ${ }^{[55]}$ 
Table 3. Isotherm parameters for the removal of $\mathrm{MB}$ and $\mathrm{CR}$ by BSG at $298.15 \mathrm{~K}$

\begin{tabular}{|c|c|c|c|}
\hline \multicolumn{2}{|c|}{ Isotherm model and parameters } & \multirow{2}{*}{$\frac{\mathrm{MB}}{12.800}$} & \multirow{2}{*}{$\frac{C R}{13.206}$} \\
\hline Langmuir & $q_{\mathrm{m} \text { exp. }} / \mathrm{mg} \mathrm{g}^{-1}$ & & \\
\hline & $q_{\mathrm{m} \text { cal. }} / \mathrm{mg} \mathrm{g}^{-1}$ & 37.45 & 19.65 \\
\hline & $K_{\mathrm{L}} / \mathrm{dm}^{3} \mathrm{mg}^{-1}$ & 0.025 & 0.114 \\
\hline & $R_{\mathrm{L}}$ & 0.213 & 0.055 \\
\hline & $R^{2}$ & 0.929 & 0.953 \\
\hline \multirow[t]{3}{*}{ Freundlich } & $K_{\mathrm{F}} /\left(\mathrm{mg} / \mathrm{g}\left(\mathrm{dm}^{3} / \mathrm{mg}\right)^{1 / \mathrm{n}}\right)$ & 0.973 & 2.090 \\
\hline & $n$ & 1.16 & 1.46 \\
\hline & $R^{2}$ & 0.993 & 0.944 \\
\hline
\end{tabular}

The data were further analysed by pseudo-secondorder chemisorption model proposed by Ho and McKay ${ }^{[53]}$ and expressed by the equation:

$$
\frac{1}{q_{t}}-\frac{1}{q_{\mathrm{e}}}=\frac{1}{k_{2} \cdot q_{\mathrm{e}}^{2} \cdot t}
$$

where $k_{2}$ (in $\mathrm{g} \mathrm{mg}^{-1} \mathrm{~min}^{-1}$ ) is the pseudo-second-order rate constant of the adsorption process. The values of $q_{\mathrm{e}}$ and $k_{2}$ were determined from the slope and intercept of the plot of $t / q_{\mathrm{t}}$ against $t$ for different initial MB and CR concentrations and the straight lines were obtained in all cases. The pseudo-second-order model assumes that the rate-limiting step that controls the adsorption might be chemisorption, i.e. chemical reactions. ${ }^{[56]}$

The kinetic parameters of the pseudo-first-order and pseudo-second-order models are summarised in Table 4. The goodness of fit was based on the correlation coefficient $\left(R^{2}\right)$ values obtained for each model and each initial concentration of $M B$ and $C R$. As can be seen from Table 4, the pseudo-second-order model appears to be better fitting than the pseudo-first-order model. Furthermore, although the $R^{2}$ values of pseudo-first-order model were relatively high, the calculated $q_{\text {ecal }}$ values are not in a good agreement with the experimental $q_{\text {exp }}$ values. On the other hand, the $q_{\text {e cal }}$ values calculated using the pseudo-secondorder model were very close to the experimental $q_{\text {e exp }}$ values. This indicates that pseudo-second-order model better describes the experimental kinetics data for both dyes, which is in a good agreement with other studies dealing both with $\mathrm{MB}^{[11,38,44,45]}$ and $\mathrm{CR} \cdot{ }^{[40,48,57]}$

\section{Intraparticle Diffusion Model}

Since pseudo-first-order and pseudo-second-order models cannot be used to describe the diffusion mechanism, Weber and Morris ${ }^{[8]}$ proposed the intraparticle diffusion model. The equation below is used to evaluate the effect of intraparticle diffusion resistance on adsorption:

$$
q_{t}=k_{i} \cdot t^{\frac{1}{2}}+C
$$

where $k_{\mathrm{i}}$ (in $\mathrm{mg} \mathrm{g}^{-1} \mathrm{~min}^{-0.5}$ ) is the intraparticle diffusion rate constant, while $C$ is providing the information regarding the boundary layer thickness (larger intercept value indicates the greater boundary layer effect). The plots of $q v s . t^{1 / 2}$ for different initial $M B$ and $C R$ concentrations are given in Figure 10, while the parameters of the intraparticle kinetic model are given in Table 5. If the plots pass through the origin, the intraparticle diffusion is the only rate-limiting step. However, if not (i.e. $C \neq 0$ ), the adsorption is to some extent also controlled by the boundary layer diffusion. ${ }^{[59]}$ The plots for both $\mathrm{MB}$ and $\mathrm{CR}$ did not pass through the origin (Figure 10, Table 5), indicating that intraparticle diffusion was not the only process that controlled the adsorption of $\mathrm{MB}$ and $\mathrm{CR}$ onto BSG. The intercepts $C$ are

Table 4. Parameters of the pseudo-first-order and pseudo-second-order kinetic models for the removal of MB and CR by BSG

\begin{tabular}{|c|c|c|c|c|c|c|c|c|}
\hline \multirow{2}{*}{ Dye } & \multicolumn{5}{|c|}{ Pseudo-first-order kinetic } & \multicolumn{3}{|c|}{ Pseudo-second-order kinetic } \\
\hline & $\gamma_{0} / \mathrm{mg} \mathrm{dm}^{-3}$ & $q_{\text {exp }} / \mathrm{mg} \mathrm{g}^{-1}$ & $k_{1} / \min ^{-1}$ & $q_{\text {e cal }} / \mathrm{mg} \mathrm{g}^{-1}$ & $R^{2}$ & $k_{2} / g g^{-1} \mathrm{~min}^{-1}$ & $q_{\text {e cal. }} / \mathrm{mg} \mathrm{g}^{-1}$ & $R^{2}$ \\
\hline \multirow{5}{*}{$\mathrm{MB}$} & 15 & 1.348 & 0.013 & 0.094 & 0.791 & 0.626 & 1.348 & 0.999 \\
\hline & 30 & 2.673 & 0.017 & 0.421 & 0.926 & 0.151 & 2.687 & 0.999 \\
\hline & 50 & 4.445 & 0.025 & 1.561 & 0.984 & 0.093 & 4.488 & 1 \\
\hline & 100 & 8.857 & 0.026 & 0.914 & 0.987 & 0.051 & 8.929 & 0.999 \\
\hline & 150 & 12.800 & 0.015 & 0.677 & 0.975 & 0.083 & 12.821 & 1 \\
\hline \multirow{5}{*}{$\mathrm{CR}$} & 15 & 1.414 & 0.029 & 0.175 & 0.822 & 0.485 & 1.424 & 1 \\
\hline & 30 & 2.886 & 0.024 & 0.966 & 0.906 & 0.065 & 2.951 & 0.999 \\
\hline & 50 & 4.736 & 0.019 & 4.864 & 0.962 & 0.027 & 4.904 & 0.999 \\
\hline & 100 & 9.215 & 0.026 & 2.159 & 0.951 & 0.009 & 9.597 & 0.999 \\
\hline & 150 & 13.206 & 0.017 & 7.216 & 0.977 & 0.006 & 13.736 & 0.998 \\
\hline
\end{tabular}
at $298.15 \mathrm{~K}$

DOI: $10.5562 /$ cca3289 

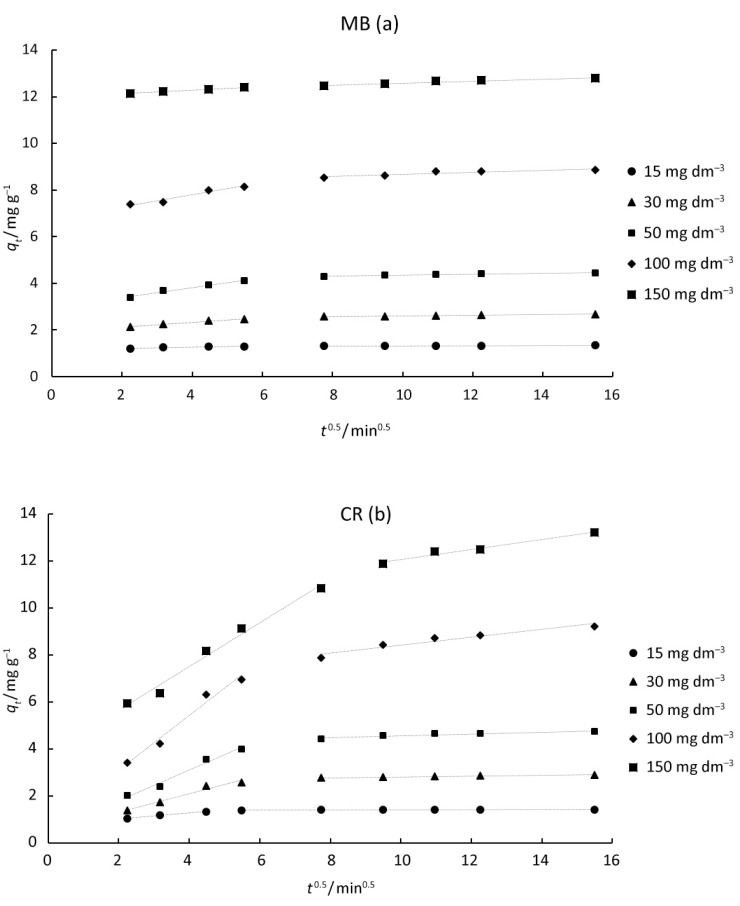

Figure 10. Weber and Morris intraparticle diffusion plots for $M B(a)$, and $C R(b)$ removal using BSG at different initial dye concentrations.

proportional to the thickness of the boundary layer and the examination of $C$ values provides the information on the extent of thickness. Furthermore, higher values of $C$ indicate higher adsorption capacities of adsorbent. ${ }^{[57]}$ The plots in Figure 10 can be separated into two linear regions, indicating more than one mode of adsorption in the uptake of $\mathrm{MB}$ and $\mathrm{CR}$ by BSG. The first linear region can probably be assigned to the adsorption at the external adsorbent surface when the uptake rate is high. The second linear region can be attributed to the gradual adsorption stage and the equilibrium stage when the effect of the intraparticle diffusion is slowing down and ceasing. Similar results were reported for adsorption of $\mathrm{MB}$ on garlic peel and jackfruit peel, ${ }^{[11,38]}$ as well as for adsorption of CR on cattail root. ${ }^{[47]}$

\section{CONCLUSION}

Brewers' spent grain (BSG), a low-cost lignocellulosic material widely available throughout the year, was found to be effective for the removal of methylene blue (MB) and congo red (CR) from buffered aqueous solutions. High removal of both dyes ranging from 70 to over $90 \%$ was achieved. The equilibrium data of both dyes were fitted to Langmuir and Freundlich isotherm models, and it was shown that in both cases (MB and CR adsorption) the process could be interpreted in terms of Langmuir and Freundlich adsorption isotherms. However, based on the $R^{2}$ values and the comparison of the calculated monolayer adsorption capacity $\left(q_{\mathrm{mcal}}\right)$ values and the experimental $\left(q_{\text {mexp }}\right)$ values, the equilibrium data of CR seem to be somewhat better fitted with Langmuir isotherm equation than MB data. The kinetic data of the adsorption process for both MB and CR were well described by the pseudosecond-order kinetic model. When experimental kinetics data were fitted using intraparticle diffusion kinetic model the results indicated that intraparticle diffusion was not the only process that controlled the adsorption of $M B$ and $C R$ onto BSG. The results showed that BSG could be used as a low-cost adsorbent for the removal of synthetic dyes $M B$ and $C R$ from aqueous solutions, with a potential use for coloured wastewaters treatment. However, further research regarding different BSG modifications in order to improve its adsorption capacity is strongly recommended.

Table 5. Parameters of the intraparticle kinetic model for the removal of MB and CR by BSG at $298.15 \mathrm{~K}$

\begin{tabular}{cccccccc}
\hline Dye & $\gamma_{0} / \mathrm{mg} \mathrm{dm}^{-3}$ & $k_{\mathrm{i} 1} / \mathrm{mg} \mathrm{g}^{-1} \mathrm{~min}^{-0.5}$ & $C_{1}$ & $R_{1}{ }^{2}$ & $k_{\mathrm{i} 1} / \mathrm{mg} \mathrm{g}^{-1} \mathrm{~min}^{-0.5}$ & $C_{2}$ & $R_{2}{ }^{2}$ \\
\hline & 15 & 0.0331 & 1.130 & 0.904 & 0.004 & 1.284 & 0.878 \\
& 30 & 0.107 & 1.897 & 0.983 & 0.014 & 2.461 & 0.973 \\
$\mathrm{MB}$ & 50 & 0.213 & 2.966 & 0.983 & 0.019 & 4.168 & 0.854 \\
& 100 & 0.261 & 6.751 & 0.959 & 0.041 & 8.275 & 0.830 \\
& 150 & 0.076 & 11.993 & 0.979 & 0.043 & 12.175 & 0.914 \\
\hline \multirow{3}{*}{$\mathrm{CR}$} & 15 & 0.132 & 0.750 & 0.991 & 0.003 & 1.369 & 0.754 \\
& 30 & 0.386 & 0.545 & 0.962 & 0.016 & 2.642 & 0.974 \\
& 50 & 0.645 & 0.515 & 0.978 & 0.037 & 4.194 & 0.893 \\
& 100 & 1.158 & 0.782 & 0.976 & 0.165 & 6.767 & 0.929 \\
& 150 & 0.931 & 3.780 & 0.983 & 0.210 & 9.963 & 0.969 \\
\hline
\end{tabular}




\section{REFERENCES}

[1] R. Gong, M. Li, C. Yang, Y. Sun, J. Chen, J. Hazard. Mater. 2005, 121, 247.

[2] Y. Wong, J. Yu, Water Res. 1999, 33, 3512.

[3] Arslan, I. A. Balcioglu, D. W. Bahnemann, Appl. Catal. B Environ. 2000, 26, 193.

[4] B. C. Burdett, C. C. Cook, J. Guthrie, JSDC 1977, 93, 55.

[5] M. S. M. Annuar, S. Adnan, S. Vikineswary, Y. Chisti, Water, Air, Soil Pollut. 2009, 202, 179.

[6] G. Crini, Bioresour. Technol. 2006, 97, 1061.

[7] N. Puvaneswari, J. Muthukrishnan, P. Gunasekaran, Indian J. Exp. Biol. 2006, 44, 618.

[8] N. Mathur, P. Bhatnagar, P. Bakre, Appl. Ecol. Environ. Res. 2006, 4, 111.

[9] G. B. Michaels, D. L. Lewis, Environ. Toxicol. Chem. 1985, 4, 45.

[10] O. Yesilada, D. Asma, S. Cing, Process Biochem. 2003, 38, 933.

[11] B. H. Hameed, A. A. Ahmad, J. Hazard. Mater. 2009, $164,870$.

[12] M. Rafatullah, O. Sulaiman, R. Hashim, A. Ahmad, J. Hazard. Mater. 2010, 177, 70.

[13] V. K. Gupta, Suhas, J. Environ. Manage. 2009, 90, 2313.

[14] T. Robinson, B. Chandran, P. Nigam, Bioresour. Technol. 2002, 85, 119.

[15] N. Velić, T. Marček, T. Jurić, K. Petrinović, D. Hasenay, L. Begović, V. Slačanac in Proceedings of 15th Ružička days "Today science - tomorrow industry" (Eds.: D. Šubarić, A. Jukić), J.J. Strossmayer University of Osijek, Faculty of Food Technology Osijek, Croatian Society of Chemical Engineers, Osijek and Zagreb, 2015, pp. 424-432.

[16] S. Sadaf, H. N. Bhatti, S. Nausheen, S. Noreen, Arch. Environ. Contam. Toxicol. 2014, 66, 557.

[17] L. W. Low, T. T. Teng, A. Ahmad, N. Morad, Y. S. Wong, Water, Air, Soil Pollut. 2011, 218, 293.

[18] T. Robinson, B. Chandran, P. Nigam, Water Res. 2002, 36, 2824.

[19] A. Kezerle, T. Jurić, N. Velić, D. Hasenay, T. Marček, D. Velić in Proceedings \& abstracts of 9th International scientific/professional conference Agriculture in nature and environment protection (Eds.: S. Rašić, P. Mijić), Glas Slavonije d.d., Osijek, 2016, pp. 204-208.

[20] V. Jaikumar, Int. J. Chem. (Toronto, ON, Can.) 2007, $1,2$.

[21] V. Dulman, S. M. Cucu-Man, J. Hazard. Mater. 2009, 162, 1457.

[22] G. Annadurai, R. S. Juang, D. J. Lee, J. Hazard. Mater. 2002, 92, 263.
[23] A. Abdolali, W. S. Guo, H. H. Ngo, S. S. Chen, N. C. Nguyen, K. L. Tung, Bioresour. Technol. 2014, 160, 57.

[24] S. I. Mussatto, G. Dragone, I. C. Roberto, J. Cereal Sci. 2006, 43, 1.

[25] K. Vanreppelen, S. Vanderheyden, T. Kuppens, S. Schreurs, J. Yperman, R. Carleer, Waste Manag. Res. 2014, 32, 634.

[26] V. Jaikumar, V. Ramamurthi, Int. J. Chem. (Toronto, ON, Can.) 2009,1, 1.

[27] J. P. Silva, S. Sousa, I. Gonçalves, J. J. Porter, S. Ferreira-Dias, Sep. Purif. Technol. 2004, 40, 163.

[28] E. Contreras, L. Sepúlveda, C. Palma, Int. J. Chem. Eng. 2012, 2012, article ID 679352, 9 pp.

[29] A. Kezerle, N. Velić, H. Pavlović, D. Velić, D. Hasenay, D. Kovačević in Proceedings Natural resources, green technology \& sustainable development 2, (Eds.: I. Radojčić Redovniković, V. Gaurina Srček, K. Radošević, T. Jakovljević, R. Stojaković, D. Erdec Hendrih), Faculty of Food Technology and Biotechnology University of Zagreb, Zagreb, 2016, pp. 95-99.

[30] S. T. Ramesh, R. Gandhimathi, T. E. Elavarasi, R. Isai Thamizh, K. Sowmya, P. V. Nidheesh, Glob Nest J. 2014, 16, 146.

[31] P. R. Ginimuge, S. D. Jyothi, J. Anaesth. Clin. Pharmacol. 2010, 26, 517.

[32] O. Hamdaoui, M. Chiha, Acta Chim. Slov. 2007, 54, 407.

[33] A. Afkhami, R. Moosavi J. Hazard. Mater. 2010, 174, 398.

[34] N. Velić, M. Tišma, I. Jozić, B. Zelić, R. Sudar, S. Keleković, A. Domaćinović in Proceedings $14^{\text {th }}$ Ružička days "Today science - tomorrow industry" (Ed.: A. Jukić), Croatian Society of Chemical Engineers, J.J. Strossmayer University of Osijek, Faculty of Food Technology Osijek, Zagreb and Osijek, 2013, pp. 187-192.

[35] TAPPI, Acid-soluble lignin in wood and pulp. Useful method 246 TAPPI. Atlanta, 1985.

[36] D. B. Rivers, B. R. Zoldak, R. S. Evans, G. H. Emert, Biotechnol. Lett. 1983, 5, 777.

[37] J. A. Robertson, K. J. A. I'Anson, J. Treimo, C. B. Faulds, T. F. Brocklehurst, V. G. H. Eijsink, K.W. Waldron, LWT - Food Sci. Technol. 2010, 43, 890.

[38] B. H. Hameed, J. Hazard. Mater. 2009, 162, 344.

[39] S. D. Khattri, M. K. Singh, Water, Air, Soil Pollut. 2000, 120, 283.

[40] W. C. Wanyonyi, J. M. Onyari, P. M. Shiundu, Energy Procedia. 2014, 50, 862.

[41] C. Namasivayam, N. Kanchana, Pertanika J. Sci. Technol. 1993, 1, 33

[42] M. H. Baek, C. O. ljagbemi, S. J. O, D. S. Kim, J. Hazard. Mater. 2010, 176, 820. 
[43] R. Abu-El-Halawa, S. A. Zabin, H. H. Abu-Sittah, Am. J. Environ. Sci. 2016, 12, 213

[44] O. Hamdaoui, J. Hazard. Mater. 2006, 135, 264.

[45] T. Yan, L. Wang, BioResources. 2013, 8, 4722

[46] D. Suteu, T. Malutan, BioResources. 2013, 8, 427.

[47] Z. Hu, H. Chen, F. Ji, S. Yuan, J. Hazard. Mater. 2010, 173, 292.

[48] H.-X. Li, R.-J. Zhang, L. Tang, J.-H. Zhanng, Z.-G. Mao, BioResources. 2014, 9, 6682.

[49] K. S. Bharathi, S. T. Ramesh, Appl. Water Sci. 2013, 3, 773.

[50] I. Langmuir, J. Am. Chem. Soc. 1918, 40, 1361.

[51] H. M. F. Freundlich, J. Phys. Chem. 1906, 57, 385.

[52] S. Lagergren, K. Svenska, Vetenskapsad Handl. 1898, $24,1$.

[53] Y. S. Ho, G. McKay, Chem. Eng. J. 1998, 70, 115.
[54] A. Juhász, E. Csapó, D. Ungor, G. K. Tóth, L. Vécsei, I. Dékány, J. Phys. Chem. B 2016,120, 7844.

[55] R. M. Ali, H. A. Hamad, M. M. Hussein, G. F. Malash, Ecol. Eng. 2016, 91, 317.

[56] S. Pap, J. Radonić, S. Trifunović, D. Adamović, I. Mihajlović, M. Vojinović Miloradov, M. Turk Sekulić, J. Environ. Manage. 2016, 184, 297.

[57] A. T. Ojedokun, O. S. Bello, Appl. Water Sci. 2017, 7, 1965.

[58] W. J. Weber, J. C. Morris in Proceedings of the International Conference on water Pollution Symposium 2. Pergamon, Oxford, 1962, pp. 231266.

[59] W. H. Cheung, Y. S. Szeto, G. McKay, Bioresour. Technol. 2007, 98, 2897. 